\title{
Safety of eyes in infants and babies during Breast feeding
}

\author{
Shripat Dixit*1, Reva Kanash ${ }^{2}$, Parvez \\ ${ }^{1}$ Eye deptt, Gomabai Netralaya India. \\ ${ }^{2}$ Cornea and Anterior segment Gomabai Netralaya India. \\ ${ }^{3}$ Oculoplasty deptt, Gomabai Netralaya India.
}

*Corresponding Author: Shripat Dixit, Eye deptt Gomabai Netralaya Nimach Madhya Pradesh India.

\section{Received Date: 06 November 2021 | Accepted Date: 17 January 2022 | Published Date: 21 January 2022}

Citation: S Dixit, R Kanash, Parvez. (2022). Safety of eyes in infants and babies during Breast feeding. International Journal of Clinical Case Reports and Reviews. 10(3); DOI: 10.31579/2690-4861/190

Copyright: (0) 2022 Shripat Dixit, This is an open-access article distributed under the terms of the Creative Commons Attribution License, which permits unrestricted use, distribution, and reproduction in any medium, provided the original author and source are credited.

\section{Abstract \\ An awareness study about the Eye safety while breast feeding in small children and infants, as there are always chances of an eye injury to the baby with the hook of mother's blouse. In India blouse is a traditional top women used to wear mostly.}

Keywords: blouse; breastfeeding; infants; lid laceration; corneal tear

\begin{abstract}
Abbreviations: Blouse is a traditional top which has been worn in pan India
\end{abstract}

\section{Introduction}

A four days old baby girl reported to our hospital in emergency followed by an injury with a hook of a blouse. On examination she was diagnosed small lid tear at upper lid. Baby's mother told that she was feeding her and suddenly she moved her head and blouse hook scratched the upper lid.

She then taken to Operating room and tear sutured under topical anesthesia. Baby's recovery was fast and uneventful on subsequent follow ups. As an eye health care provider we noticed that there are lots of trauma cases are being reported to us with history of injury with a hook of blouse while breast feeding to their babies. This is typically happening with the blouse only because in rural part women do veil and due to veil women some time cannot see well that hook comes very close to the baby's eye and causes trauma. So we decided to start an awareness campaign in our cataract screening camps. This awareness made an huge impact which could avoid such injury.

https://www.escrs.org/paris2019/programme/posters-

details.asp? $\mathrm{id}=33353$

https://www.ncbi.nlm.nih.gov/pmc/articles/PMC3729650/

\section{Materials and Methods}

Routine Instruments like Torch, Hand held slit lamp and Operating Microscope and surgical instruments set for trauma repair. 

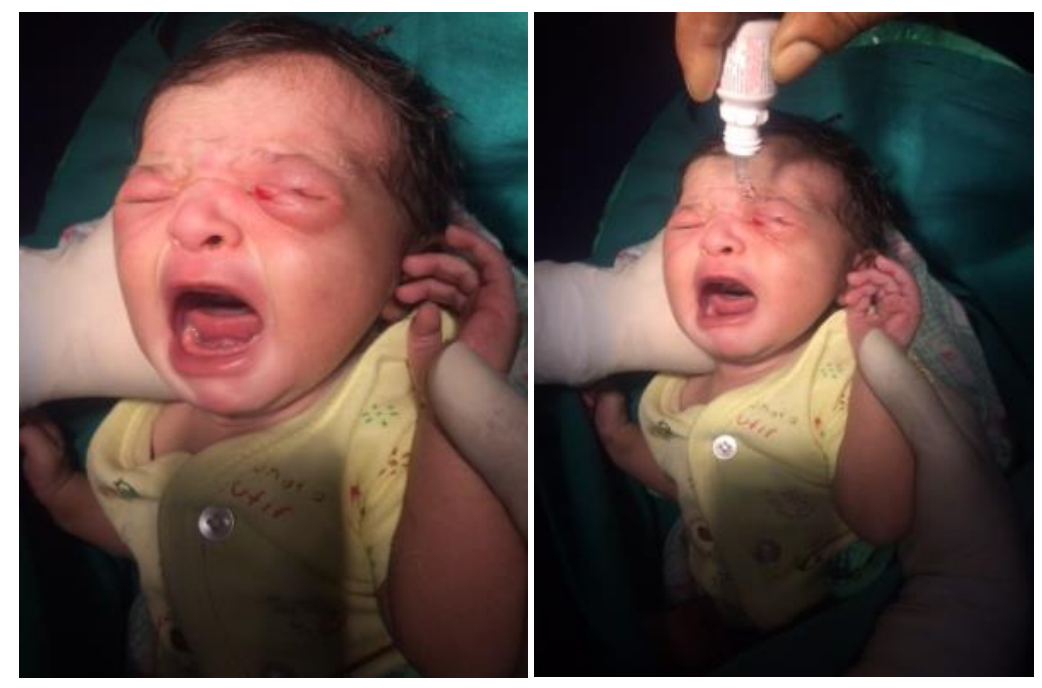

\section{Results and Discussion}

Early surgical interventions gave very good results in terms of good contour of lid and Corneal shape although visual out comes yet to measured but in subsequent follow ups babies look comfortable.

\section{Conclusion}

We need to spread this message in our society that mothers have to be extra careful while feeding their child. Even our Gynecologists should also explain the soft stretchable cloth top without hooks or pin to avoid any trauma.

\section{Acknowledgement}

We acknowledge my sincere thanks to our hospital management, IT team, colleagues in OPD and OT Ms Vimla Rai and Mr KS Nagda for their valuable support to carry out this awareness programme.

\section{Conflict of interest}

There is no conflict about it.

\section{Financial Interest}

There is no financial interest to do the study.

\section{Reference:}

1. European society of cataract \& refractive surgeons. (2019). 37th congress of the European society of cataract \& refractive surgeons.

2. Nazri Omar and Rafidah Salleh. (2009). Eyelid hook injury - A preventable domestic injury. Saudi Journal of Ophthalmology. 23(3-4):219-220.
This work is licensed under Creative Commons Attribution 4.0 License

To Submit Your Article Click Here:

\section{Submit Manuscript}

Ready to submit your research? Choose Auctores and benefit from:

$>$ fast, convenient online submission

$>$ rigorous peer review by experienced research in your field

$>$ rapid publication on acceptance

$>$ authors retain copyrights

$>$ unique DOI for all articles

$>$ immediate, unrestricted online access

At Auctores, research is always in progress.

Learn more https://auctoresonline.org/journals/international-journal-of-clinicalcase-reports-and-reviews 